\title{
Anti-DKK-1 Monoclonal Antibody LY2812176
}

National Cancer Institute

\section{Source}

National Cancer Institute. Anti-DKK-1 Monoclonal Antibody LY2812176. NCI Thesaurus. Code $C 99123$.

A human monoclonal antibody directed against the WNT antagonist dickkopf homolog 1 (DKK1), with potential anti-osteolytic activity. Anti-DKK1 monoclonal antibody LY2812176 binds to and inhibits DKK1, thereby restoring signaling through the WNT pathway, which may result in osteoblast differentiation and activation within the bone matrix and the reversal of tumor-induced osteolytic disease. DKK1, overexpressed by myeloma cells, is an inhibitor of the WNT signaling pathway and prevents the mediated formation of bone. 